\title{
PALEOECOLOGY OF RANGE LIMITS: BEECH IN THE UPPER PENINSULA OF MICHIGAN ${ }^{1}$
}

\author{
KERRY D. WOODS \\ Science Division, Bennington College, Bennington, Vermont 05201 USA
}

AND

MARgaret B. DAVIS

Department of Ecology and Behavioral Biology, University of Minnesota, Minneapolis, Minnesota 55455 USA

\begin{abstract}
Fossil pollen was used to map American beech (Fagus grandifolia) populations in Wisconsin and Michigan during the last 8000 yr. Among questions addressed were: (1) What were routes and rates of range expansion? (2) Did range expansion follow a "wave-front" model or occur by coalescence of outliers? (3) Has the range of beech been determined by environmental tolerance or by dispersal rate?

Presettlement distributions were mapped from survey records. Range expansion was reconstructed using pollen diagrams from 34 sites, most in a 30-50 km grid. We show beech moving through southern Michigan into Wisconsin and Michigan's Upper Peninsula. During much of the last $8000 \mathrm{yr}$ the range of beech was relatively stable and presumably environmentally controlled. Brief delays may have been occasioned by dispersal barriers. Range expansions occurred during the last millennium, as well as 3000-2500 yr ago and 8000-5000 yr ago. Several separate colonizations across Lake Michigan formed temporary outliers. No other past outliers were detected, although modern outliers are known; however, even with closely spaced sites, outliers may have been undetected.
\end{abstract}

Key words: American beech; Fagus grandifolia; Michigan; paleoecology; palynology; range limits; seed dispersal; Wisconsin.

\section{INTRODUCTION}

Holocene range changes of North American trees have generally been studied on a continental scale (Davis 1976, Bernabo and Webb 1977, Davis 1981, Bennett 1985, Webb 1987; but see Jacobson 1979). Increased numbers of palynological sites now permit higher ("regional") resolution in reconstruction of past ranges and patterns of range expansion for individual species (e.g., Bernabo 1981, Grimm 1983, 1984, Davis and Jacobson 1985). We use a grid of closely spaced palynological sites to add both temporal and spatial detail in a regional reconstruction of the Holocene expansion of American beech (Fagus grandifolia) populations into Wisconsin and Michigan. Our results provide a case study for assessing modes of range expansion and the determinants of range limits.

Range limits are often thought to be climatically determined. Many investigators (Iversen 1944, Conolly and Dahl 1970, Pigott and Huntley 1978, Stowe and Teeri 1978, Teeri et al. 1978) have inferred species' physiological tolerances by examining temperature or rainfall isopleths or substrate boundaries that coincide geographically with range limits. Bennett (1985) suggests that range has generally been environmentally

${ }^{1}$ Manuscript received 14 December 1987; revised 16 May 1988; accepted 23 May 1988; final version received 23 June 1988. determined, though population sizes may have lagged in reaching environmentally determined maxima. The assumption of vegetation-environment equilibrium is reflected in frequent definition of community types by species' range limits; range limits, if environmentally determined, provide meaningful natural boundaries between communities (e.g., Curtis 1959, Kuchler 1966, Daubenmire 1968), especially in situations where habitat-specific management regimes are called for. A further implication is that past range changes were associated with changes in environment, usually interpreted as climate. Questions of vegetation-climate equilibrium, including assumptions about range limits and response times for range expansion have been critically addressed by Davis (1978), Birks (1981), Wright (1984), and in a recent symposium (Brubaker 1986, Davis et al. 1986, Pennington 1986, Prentice 1986, T. Webb 1986).

A species' range is defined by the presence of mature, reproducing individuals even though pre-reproductive individuals may exist beyond this range. If dispersal capability is limited, range expansion should occur as a frontal movement with no individuals becoming established at any large distance from the main body of the population. In this "wave-front" model, barriers of unsuitable habitat would slow or stop expansion and a species might be prevented or delayed from reaching a distribution in equilibrium with regional climate. Al- 


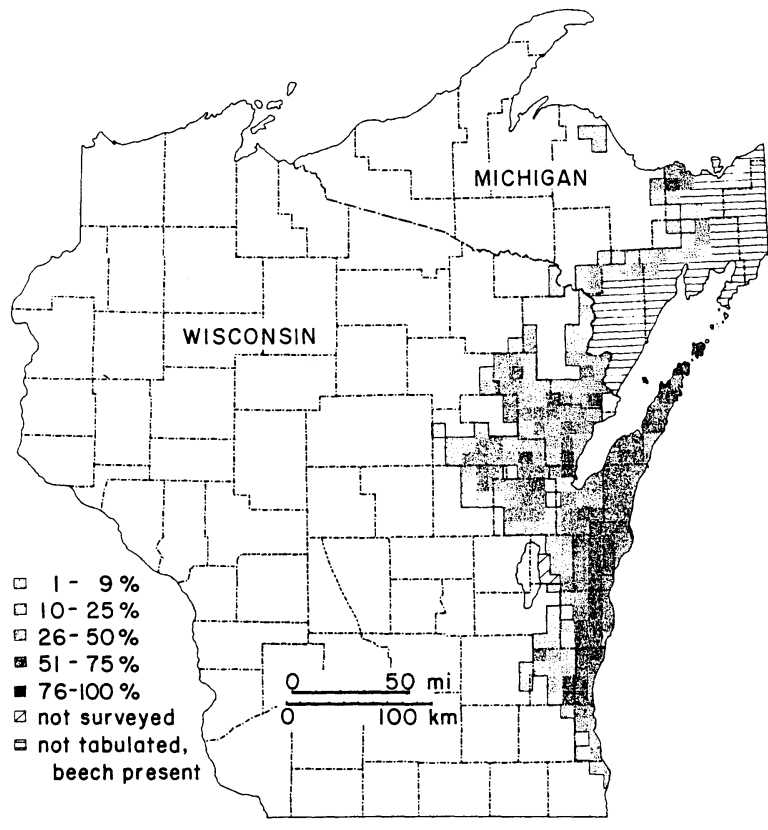

FIG. 1. Presettlement distribution of beech near its limit in Michigan and Wisconsin. Density of stippling indicates percentage of all section lines in a township along which beech was recorded. The solid line encloses all townships in which beech was noted in the General Land Office surveys.

ternatively, range expansion could involve occasional dispersal of propagules over distances of hundreds or thousands of metres to establish outlying populations that may eventually merge (see Bennett 1985, Johnson and Adkisson 1985 concerning beech). Even if such dispersal is rare, this "outlier" model could allow relatively rapid extension of a species' range and crossing of habitat barriers, making equilibrium with climate more likely. Pielou (1979) defines "jump-dispersal" and "diffusion" modes of spread of species, but jumpdispersal, in her definition, refers generally to founding of populations that remain isolated. Both of our models constitute diffusion in her terminology, but at higher spatial resolution.

American beech (Fagus grandifolia) is a dominant in late-successional forests of eastern North America from the Gulf of Mexico to the southern margins of the boreal forest. It is one of the most shade-tolerant and long-lived species in Eastern forests, but is intolerant of fire. Typically, it is dominant on mesic sites on somewhat acidic, loamy soils with high humus content (Fowells 1965), generally Spodosols and Alfisols. In the Upper Great Lakes region it is found throughout lower Michigan and Indiana, but only in extreme eastern Illinois and Wisconsin and the eastern half of the Upper Peninsula of Michigan. In Michigan and northern Wisconsin, the current range limit is not congruent with any other obvious vegetational boundary. Other species co-dominant with beech-sugar maple (Acer saccharum), yellow birch (Betula lutea), and eastern hemlock (Tsuga canadensis)-occur in mature mesic forests farther west, and such stands from both sides of the range limit of beech are generally lumped together in vegetation classifications and maps (e.g., "hemlock-white pine-northern hardwood" of Braun 1950 and "northern hardwoods-fir" of Kuchler 1966).

\section{Definition OF Modern RANGe}

To supplement small-scale maps of beech distribution (e.g., Little 1970), we used General Land Office Survey notes to prepare a large-scale map of beech near its range limit in Michigan and Wisconsin (Fig. 1). Survey notes from the early 19 th century for northern Michigan identify two "witness trees" at each section and quarter-section corner and additional "line" trees. Wisconsin surveys are similar but record four trees per section corner. Surveyors also made general observations of forest composition. We noted all section lines along which beech was reported as witness trees or in forest descriptions. Survey records can be unreliable for quantitative forest reconstruction and in identification of some species (Bourdo 1956, Grimm 1984); however, we were concerned primarily with the presence of beech, which is unlikely to be misidentified and which was probably favored-as a witness tree because it is easy to mark.

The range limit, as recorded in Land Survey data, is generalized to the township level, including all townships in which any beech trees were recorded (Fig. 1). At this resolution the range of beech is nearly continuous. Two outlying populations are shown, the most remote and extensive in Michigan $\approx 30 \mathrm{~km}$ northwest of the main range near Lake Superior, and a second on the Michigan-Wisconsin border.

The Land Survey sample is more thorough than any other systematic data set available for large areas, but sample density is low, a minimum of 2.3 trees $/ \mathrm{km}^{2}$ (six trees per square mile), and transects are widely spaced. Field observation revealed several small $(\leq 100$ mature trees) outlying populations up to $10 \mathrm{~km}$ beyond the range limit shown in Fig. 1. These were established before the end of the 19th century; large, old trees were seen at all sites. Additional small outliers, now destroyed, may have been missed in the Survey, and sparse populations may have connected some apparent outliers with the main range. Isolated seedlings and saplings, which may not reach maturity, have been reported up to $15 \mathrm{~km}$ beyond the limit of beech shown in Fig. 1 (F. Metzger, United States Forest Service, personal communication). The importance of resolution in defining range limits is obvious; Little (1970) draws a limit that encompasses outliers shown in Fig. 1 within the main body of the range.

The proportion of section lines within each township where beech trees were reported gives an impression of beech density (Fig. 1). Beech was (and still is) especially dense in presettlement forests at its range limit near Lake Superior. Beech was also abundant in Wis- 


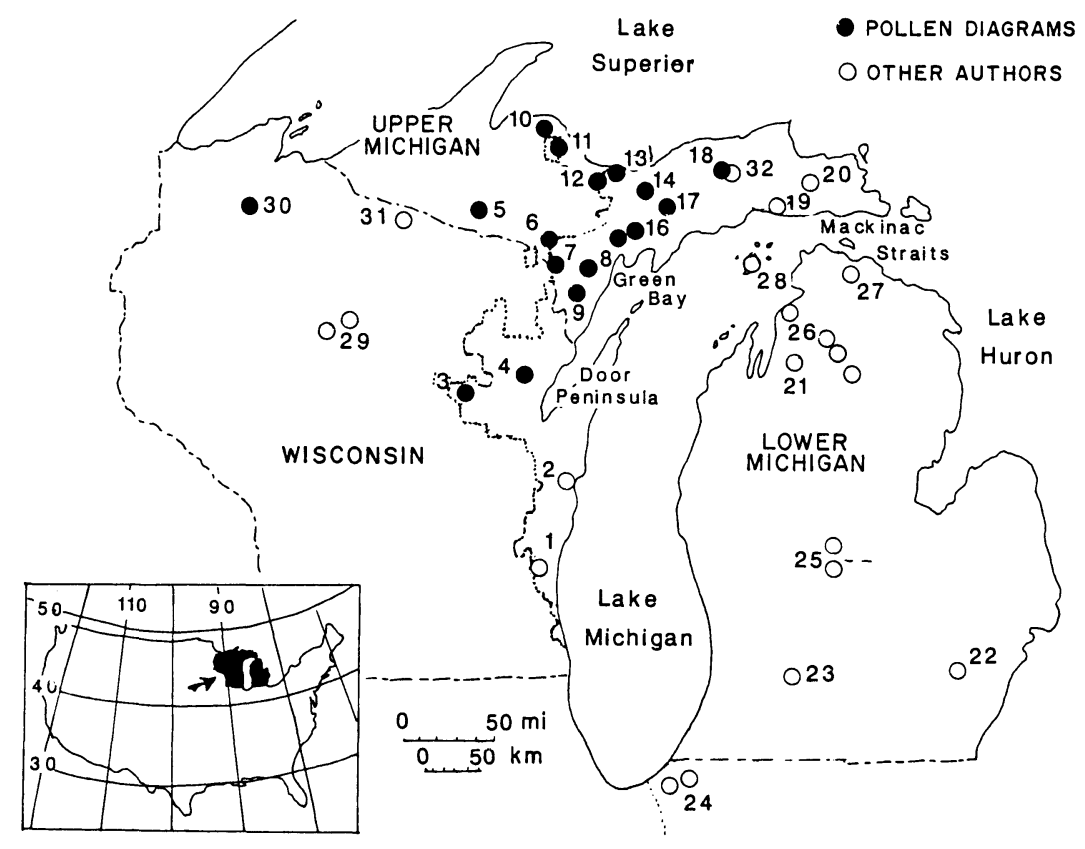

FIG. 2. Pollen sites used in reconstruction of the history of beech populations in Michigan and Wisconsin. Names and information for each site are in Table 1. Beech range limit (from Fig. 1) is shown by dotted line. $\bullet$ unpublished diagrams from this and related studies. $O$ sites studied by other workers and in the literature.

consin on the Door Peninsula. Brown (1984) makes the generalization that species generally decline in abundance as their distributional limit is approached. Although townships with sparse populations of beech are the rule near the range limit, local abundances within a few kilometres of the range limit can be as great as those nearer the heart of its range (Fig. 1, Woods 1981). Lacunae or areas of low density within the range generally correspond to extensive areas of obviously unsuitable or marginal habitat such as extensive peatlands, coarse sands, or floodplains.

\section{History of BeEch Populations in the UPPER GREAT LAKES REGION}

\section{Methods}

Construction of pollen diagrams and maps. - Reconstruction of routes of range expansion and measurement of rates required a grid of palynological sample sites (Table 1, Fig. 2). We prepared complete, dated pollen diagrams for beech for 16 lakes along and just within the range limit of beech in Wisconsin and upper Michigan. An effort was made to locate lakes in a grid pattern with $30-50 \mathrm{~km}$ between lakes, but lack of suitable sites in some areas led to irregularities in the grid. Lakes were generally $2-5$ ha in area (Table 1 ), without large inlet or outlet streams, and immediately adjacent to forested areas with beech trees. Since beech pollen deposition is regular within small lake basins (Davis et al. 1971), a single core from deep water for each lake was judged to be sufficient. Cores were taken with a 6.25-cm diameter Livingstone corer (Wright 1967). Published and unpublished diagrams from 11 additional sites over a more extensive area supplemented our sample; some of these lakes were relatively large (Table 1).

Samples $\left(1 \mathrm{~cm}^{3}\right)$ were taken at intervals from sediment cores, pollen was extracted and acetolyzed (Faegri and Iversen 1975), and 300-500 grains of terrestrial pollen were counted per level. Samples were spiked with known quantities of Eucalyptus pollen for calculation of absolute concentrations (Benninghoff 1962). Radiocarbon dates were obtained from several levels in each core, usually including the level of first increase in beech pollen, the European settlement horizon (marked by increases in weedy pollen types), and the hemlock decline where discernible. Dates for the settlement horizon and for the hemlock decline (established at $\approx 4850$ yr BP; Webb 1982, Allison et al. 1986) were used to correct for systematic dating errors due to the presence of nonequilibrium carbon. Corrections were applied for sites 7,8 , and 9 (Table 1), all in areas of limey soils. Age-depth curves were fitted to scatter plots of radiocarbon age vs. depth by linear interpolation between dated points (except for Spirit and Hoglund Lakes, where age-depth relationships were fitted by linear regression on dated levels).

Pollen frequencies, calculated as percent total terrestrial pollen, were plotted against age. Interpretation of percentage diagrams is complicated by the interdependence of frequencies for different taxa. Pollen concentrations and accumulation rates, however, are 
TABLE 1. Characteristics of sites for sediment cores.

\begin{tabular}{|c|c|c|c|c|c|c|c|c|c|c|c|c|}
\hline $\begin{array}{l}\text { Site } \\
\text { num- } \\
\text { ber }\end{array}$ & Name & Latitude & Longitude & $\begin{array}{l}\text { Site } \\
\text { area } \\
\text { (ha) }\end{array}$ & $\begin{array}{l}\text { Maxi- } \\
\text { mum } \\
\text { depth } \\
\text { (m) }\end{array}$ & $\begin{array}{l}\text { Sediment } \\
\text { depth } \\
\text { (cm) }\end{array}$ & $\begin{array}{l}\text { No. } \\
\text { dates }\end{array}$ & $\begin{array}{l}\text { Depth } \\
\text { to } \\
\text { beech } \\
\text { in- } \\
\text { crease } \\
(\mathrm{cm})\end{array}$ & $\begin{array}{l}\text { Depth } \\
\text { to } \\
\text { near- } \\
\text { est } \\
\text { dated } \\
\text { level } \\
\text { (cm) }\end{array}$ & $\begin{array}{l}\text { Age of } \\
\text { beech } \\
\text { in- } \\
\text { crease } \\
\text { (yr } \\
\text { BP) }\end{array}$ & $\begin{array}{c}\text { Maxi- } \\
\text { mum } \\
\text { beech } \\
\text { pollen } \\
(\%)\end{array}$ & $\begin{array}{l}\text { Age of } \\
\text { beech } \\
\text { maxi- } \\
\text { mum } \\
\text { (yr } \\
\text { BP) }\end{array}$ \\
\hline 1 & Radtke $^{1}$ & $43^{\circ} 28^{\prime}$ & $88^{\circ} 6^{\prime}$ & 3 & 3.8 & 800 & 1 & 568 & 8 & 6250 & 6 & 2000 \\
\hline 4 & Beaver & $44^{\circ} 55^{\prime}$ & $88^{\circ} 9^{\prime}$ & 3.5 & 6.2 & 600 & 3 & 160 & 20 & 285 & 7 & 2000 \\
\hline 5 & Morrison & $46^{\circ} 10^{\prime}$ & $88^{\circ} 37^{\prime}$ & 3 & 5.4 & 530 & 5 & $\ldots *$ & $\cdots$ & $\cdots$ & 0.5 & 28 \\
\hline 6 & Blue Indian & $45^{\circ} 55^{\prime}$ & $87^{\circ} 51^{\prime}$ & 3 & 0.5 & 1090 & 2 & 240 & 10 & 1000 & 2 & 1000 \\
\hline 7 & Brandt's & $45^{\circ} 38^{\prime}$ & $87^{\circ} 46^{\prime}$ & 5 & 1 & 700 & 4 & 260 & 10 & 2170 & 2.4 & 800 \\
\hline 8 & Kitchner & $45^{\circ} 40^{\prime}$ & $87^{\circ} 27^{\prime}$ & 4 & 2 & 8 & 4 & 310 & 0 & 4160 & 8.7 & 1500 \\
\hline 9 & Hoglund & $45^{\circ} 29^{\prime}$ & $87^{\circ} 29^{\prime}$ & 4 & 0.9 & 339 & 3 & 125 & 5 & 4000 & 5 & 1000 \\
\hline 14 & Ackerman & $46^{\circ} 20^{\prime}$ & $86^{\circ} 47^{\prime}$ & 5 & 14 & $175 \dagger$ & 2 & 105 & 25 & 2700 & 13 & 1000 \\
\hline 15 & Brampton & $45^{\circ} 56^{\prime}$ & $87^{\circ} 1^{\prime}$ & 9.5 & 1.5 & 105 & 2 & 55 & 35 & 1000 & 2 & 1000 \\
\hline 16 & MacDonald & $46^{\circ} 2^{\prime}$ & $86^{\circ} 48^{\prime}$ & 12 & 1.4 & 1000 & 4 & 400 & 5 & 2800 & 4 & 1000 \\
\hline 17 & Lorraine & $46^{\circ} 9^{\prime}$ & $85^{\circ} 29^{\prime}$ & 5.5 & 1 & 965 & 2 & 520 & 0 & 2700 & 6 & 1500 \\
\hline 18 & Young & $46^{\circ} 27^{\prime}$ & $85^{\circ} 43^{\prime}$ & 2.5 & 11 & 268 & 3 & 155 & 5 & 2700 & 17 & 1000 \\
\hline 19 & Ryerse $^{2}$ & $46^{\circ} 8^{\prime}$ & $85^{\circ} 11^{\prime}$ & 8 & 1.5 & 225 & 6 & 188 & 12 & 2700 & 9 & 1000 \\
\hline 20 & E. Soldier ${ }^{2}$ & $46^{\circ} 21^{\prime}$ & $84^{\circ} 51^{\prime}$ & 4.8 & 2.8 & 340 & 4 & 145 & 45 & 3000 & 2 & 1000 \\
\hline 21 & Green $^{3}$ & $44^{\circ} 53^{\prime}$ & $85^{\circ} 07^{\prime}$ & 16.2 & 17.7 & 390 & 3 & 115 & 35 & 5400 & 28 & 3000 \\
\hline 22 & Frains $^{4}$ & $42^{\circ} 20^{\prime}$ & $83^{\circ} 38^{\prime}$ & 6.6 & 9.2 & 1700 & 9 & 1000 & 0 & 8000 & 20 & 3000 \\
\hline 23 & Wintergreen ${ }^{5}$ & $42^{\circ} 25^{\prime}$ & $85^{\circ} 23^{\prime}$ & 14.6 & 6.3 & 720 & 10 & 443 & 60 & 7500 & 22 & 1500 \\
\hline $24 a$ & Clear $^{6}$ & $41^{\circ} 40^{\prime}$ & $86^{\circ} 30^{\prime}$ & 20 & 1.3 & 825 & 5 & 605 & 85 & 7500 & 14 & 1000 \\
\hline $24 b$ & Hudson ${ }^{6}$ & $41^{\circ} 40^{\prime}$ & $86^{\circ} 30^{\prime}$ & 175 & 11.5 & 730 & 6 & 513 & 47 & 8000 & 21 & 1700 \\
\hline
\end{tabular}

Sources: (1) Webb 1983; (2) Futyma 1982; (3) Lawrenz 1975; (4) Kerfoot 1974; (5) Bailey 1977, Manny et al. 1978; (6) Bailey 1972; (7) Gilliam et al. 1967; (8) Bernabo 1981; (9) D. Futyma (personal communication); (10) Kapp et al. 1969; (11) Heide 1981; (12) Webb 1974.

* Not applicable.

† Complete sediment core not taken.

$\ddagger$ Information not available.

strongly dependent on characteristics of the deposition basin, so differences among sites may not represent differences in vegetation composition. We used percentage diagrams for comparisons of vegetation development among sites, inspecting concentration data for each site to avoid errors due to the use of pollen percentages. Total pollen concentrations were relatively constant for the periods of concern, so further discussion will rely on percentage data.

Beech pollen percentages for dates at 500 -yr intervals were extracted from diagrams and used to construct maps of beech pollen frequencies over the study area. Percentages used were interpolated between nearest counted levels above and below each target date (Webb et al. 1983).

Interpretation of beech pollen percentages. - In pre- settlement sediments from small lakes in Wisconsin and Michigan, beech pollen percentages drop sharply with increasing distance from the presettlement range limit of beech (M. B. Davis, M. W. Schwartz, K. D. Woods, and S. L. Webb, personal observation). At sites $>15-20 \mathrm{~km}$ outside the range limit (Fig. 1) beech pollen frequencies never reach $1.0 \%$ and percentages of $0.5 \%$ are reached only rarely and inconsistently. Consistent occurrence of beech pollen, over several counted levels, at $0.5-1.0 \%$ is strong evidence that beech populations existed within $20 \mathrm{~km}$, and frequencies $>1.0 \%$ indicate presence within that distance with near certainty. Thus, the location of the species limit can be determined with certainty only to within $15-20 \mathrm{~km}$, even with pollen sites on a $20-\mathrm{km}$ grid. Outliers, then, can be distinguished from the main species range only 
if they are separated by $>30 \mathrm{~km}$ (Davis et al. 1986); even then, placement and nature of palynological sites is critical.

In our grid sampling scheme, areas without beech should be represented by groups of sites with beech pollen at frequencies of $0-0.5 \%$. Sites with $>0.5 \%$ fossil beech pollen, surrounded by sites with no beech pollen or only trace quantities, should indicate outlying populations. The species limit should be represented by a band of sites with $0.5-1.0 \%$ beech pollen, bordered on one side by a series of sites with beech pollen at 0 $0.5 \%$ and on the other by a series of sites with higher percentages. Ambiguously low pollen percentages may sometimes be due either to small, local populations or large, distant populations.

Bennett (1985) warns of Type II error in testing for presence of beech. He suggests that consistent occurrence of pollen at any frequency should be interpreted as indicating "local" presence of beech. Our data suggest this is probably appropriate for studies at a coarser, continental scale. It may be, however, that pollen transported from large populations (thousands of trees) 30 $\mathrm{km}$ or more from a deposition site (not "local" in our study) could produce consistent frequencies of $0-0.5 \%$ (generally one or two grains per counted level). Sites showing consistent frequencies at this level prior to sustained increases are nearly always adjacent $(<40$ $\mathrm{km}$ ) to sites with higher percentages of beech pollen. Adoption of Bennett's criterion, therefore, would not change our interpretation of the sequence and spacing of events in general.

At most sites beech pollen increased from sporadic occurrences of $<0.5 \%$ to consistent occurrence $>1 \%$ within a brief interval, producing an unambiguous horizon for arrival (establishment of local populations) of beech. In some pollen diagrams, from sites just within the modern range of beech, percentages never exceeded $1.0 \%$. Although scattered beech trees occur within a hundred metres of both Abraham (site 12, in the westernmost township within the range of beech) and Second Bass Lakes (site 11, at the edge of a large outlier), maximum pollen percentages are only $\approx 1.0 \%$. At such sites we judged pollen evidence for local establishment of beech to be a change from sporadic occurrences of pollen rarely exceeding $0.5 \%$ to consistent presence of pollen with frequencies generally $>0.5 \%$. We supported this judgment by comparing pollen percentages below and above several potential points of beech establishment in the pollen diagram. Beech percentages for levels above and below a point may be treated as two samples and a rank-sum test used to test the hypothesis that the samples are from the same population (i.e., that there is no significant change in pollen frequencies across the point). In all cases our establishment date produced the rank-sum statistic of highest significance value. This is not a simple statistical test of a particular establishment date because many tests of the same hypothesis were per- formed, but results of the test provided support for our choice of levels where significant changes in beech pollen frequency occurred.

"Establishment" of beech, by our criteria, means establishment of trees within the area producing most of the pollen deposited at a site, but this area is difficult to define. Bradshaw and Webb (1985) suggest that few beech pollen are dispersed $>4.5 \mathrm{~km}$, and Schwartz (1985) shows strongest correlations between beech pollen frequency and beech abundance in forests within $5 \mathrm{~km}$ of the pollen site. In using a sampling grid with $30 \mathrm{~km}$ or more spacing, we have probably left unsampled large areas of landscape in which small, outlying populations of beech may have existed undetected. Thus, the event we recognize as "arrival" may sometimes represent expansion of preexisting but undetected small colonies (see Bennett 1985).

\section{Results: history of beech range expansion}

Pollen diagrams for Kitchner (site 8) and Spirit (site 13) Lakes (Fig. 3) show stratigraphies typical of the primary study area in central upper Michigan and adjacent Wisconsin. Spirit Lake is on acidic bedrock with very thin overlying till, while Kitchner Lake, $90 \mathrm{~km}$ south, is on shallow till over dolomite. At both sites, total pine pollen reached maximum frequencies $\approx 7000$ yr ago and declined steadily until $\approx 3000 \mathrm{yr}$ ago. Birch (Betula) pollen percentages show a concurrent gradual increase. At both sites hemlock (Tsuga canadensis) and maple (Acer spp.) pollen first appeared in significant amounts 5000-6000 yr ago; hemlock pollen percentages rapidly increased and fell at the time of the hemlock decline (Allison et al. 1986) at Spirit Lake, but this increase was slower and later at Kitchner, where hemlock may not have arrived until after the hemlock decline. From the period of hemlock recovery to the present, pollen assemblages are relatively stable; beech arrived at both sites during this interval. Total pollen concentrations have been relatively constant since $\approx 6000$ yr ago, so interpretive problems due to artifacts of percentage treatment are unlikely. Near the top of the diagrams, herbaceous pollen percentages increased and the percentages of many tree species declined, indicating forest clearance and Euroamerican settlement 100-125 yr ago.

Maps of beech pollen percentages at 500-yr intervals provide a summary view of regional changes in beech pollen frequencies (Fig. 4), but much information is lost, and, without the context of percentages from older and younger sediments, misinterpretation of single percentage values is possible. Fig. 5 gives additional information, showing beech pollen percentages for all counted levels plotted against time for each of the sites that we studied and for a selection of the sites from the literature. Decisions concerning time of local establishment of beech were based on these curves, in the context of full diagrams and diagrams from neighboring sites. Our evaluation of arrival dates for sites 

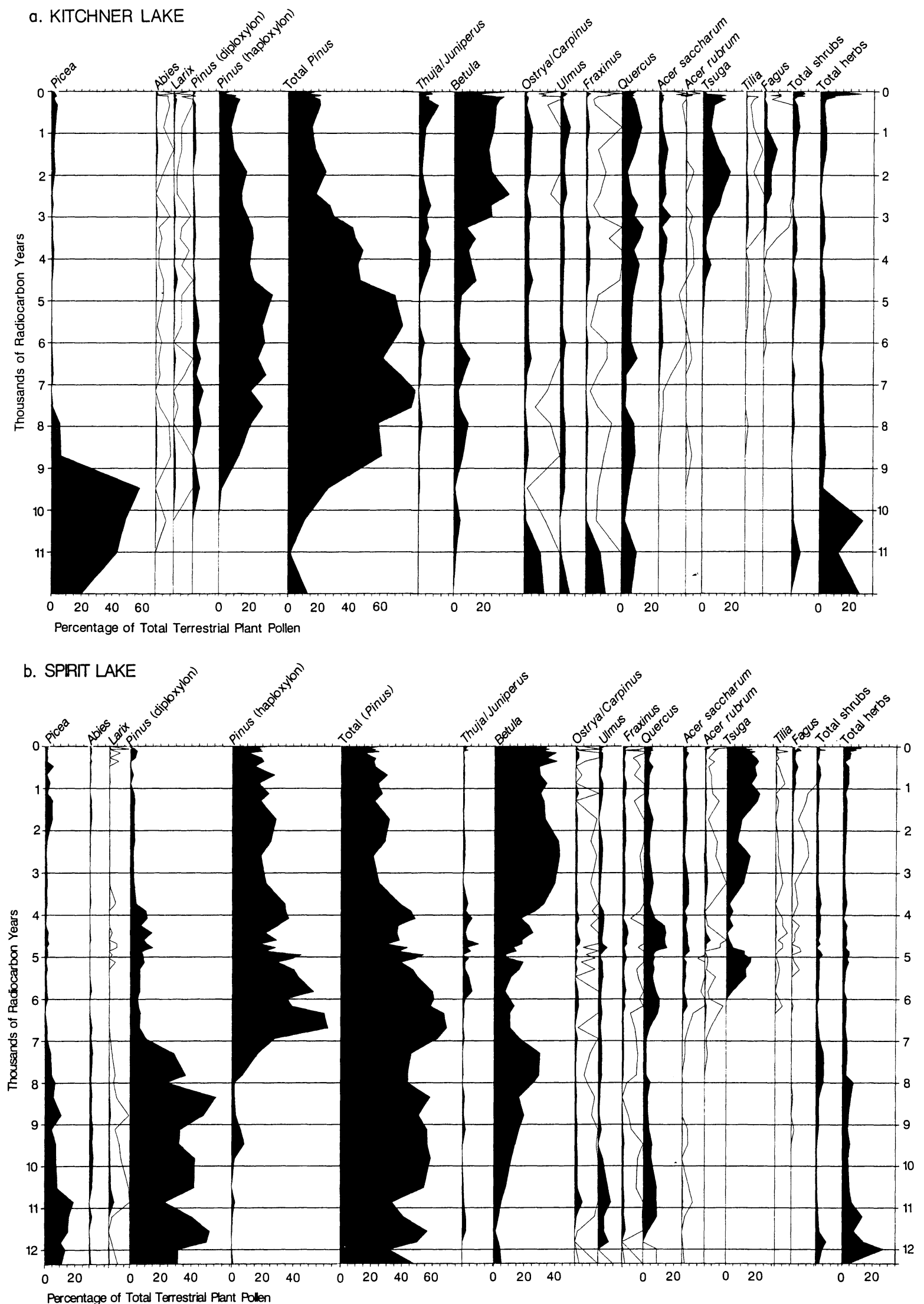
studied by other workers was based directly on percentage diagrams rather than on other authors' interpretations.

Beech entered southern Michigan $\approx 7500 \mathrm{yr}$ ago, reaching sites in the northernmost Lower Peninsula of Michigan by $\approx 4500 \mathrm{yr}$ ago (sites 21-27) (Kapp 1977). Arrival on Beaver Island in northern Lake Michigan (site 28) apparently occurred between 5000 and 4000 yr ago (Kapp et al. 1969); we are waiting for more complete dating on a site on North Manitou Island. Because large gaps separate sites in the Lower Peninsula, northward expansion of beech may have occurred at a constant or variable rate. Any interruptions must have been minor, as the net rate of range expansion was rapid $(\approx 140 \mathrm{~m} / \mathrm{yr})$.

Beech colonized the western and northern shores of Lake Michigan, in Wisconsin and upper Michigan, in at least three independent episodes. All appear to have involved delays of $1000 \mathrm{yr}$ or more in crossing Lake Michigan. Beech was first established in southern Wisconsin 6000-5000 yr ago (Fig. 4), $\approx 1000 \mathrm{yr}$ after its arrival on the eastern side of the lake in southern Michigan (S. L. Webb 1983, 1986, 1987). "Stepping stones" of suitable habitat for beech may have been present in sheltered ravines around the shore of Lake Michigan in Illinois and Wisconsin (Jensen 1928, Moran 1978), so long-distance dispersal may not have been required for this colonization (S. L. Webb 1987). Beech populations in southern Wisconsin did not expand westward, probably because of climatic limitations. Webb's sites are close to the range limit in presettlement time and there is no evidence that beech was ever abundant at these sites. For unknown reasons beech did not expand northward as far as Beaver Lake (site 4) in eastern Wisconsin for several millennia (Figs. 4 and 5). Earlier northward expansion along the lakeshore into the Door Peninsula is possible; a pollen site there is currently under investigation (J. Leekens-Mack, University of Minnesota, personal communication).

The earliest evidence for colonies in the Upper Peninsula of Michigan was found at Hoglund and Kitchner Lakes (sites 8 and 9), west of Green Bay. Populations were established there between 3500 and $4000 \mathrm{yr}$ ago, 500-1000 yr later than at sites on the eastern shore of Lake Michigan (Figs. 4 and 5). Dates for both Kitchner and Hoglund Lakes include a correction for nonequi- librium carbon (both are in areas with abundant dolomite), so our age estimates of local populations are conservative (without correction, establishment dates for these sites would be $4000-4500 \mathrm{yr}$ ago). These populations are apparently not due to expansion of populations up the western shore of Lake Michigan from Wisconsin, since arrival at Beaver Lake (site 4), farther south, was significantly later (Figs. 4 and 5). Dispersal was either across Green Bay from the Door Peninsula, or across Lake Michigan from the Lower Peninsula of Michigan. No clear range expansion occurred after 3500 yr ago for the next 1000 yr. However, some sites in the eastern Upper Peninsula of Michigan show occurrences of beech pollen in the ambiguous $0-0.5 \%$ range during this time (Fig. 4).

Between 2800 and 2600 yr ago, frequencies of beech pollen increased to $>1 \%$ at seven sites over a large area of the eastern Upper Peninsula of Michigan (Fig. 4). Within the resolution of our dating techniques $( \pm 300$ yr according to Webb 1982), this appearance is simultaneous. Beech pollen also occurs at marginal frequencies at Brandt's Lake (site 7), near the early colony at Kitchner Lake on the western shore of Green Bay, about 2700 yr ago (Fig. 5), indicating either a small local population, or increasing density of older populations to the east. At about the same time beech was established in northeastern Wisconsin, near Beaver Lake (site 4). At Kroening Lake (site 3), immediately west of Beaver Lake, beech pollen briefly increased to marginal levels but then dropped again to background levels (Fig. 5). Populations may have become established locally, and then disappeared, or higher counts may represent pollen transported from populations to the east. Expansion along the western shore of Lake Michigan to these sites could have occurred from the north (Hoglund Lake), or from the south (Gass Lake).

By 2600 yr ago only small areas near the current limits of the range of beech remained unoccupied (Fig. 4). Further expansion seems to have occurred more slowly. Between 2600 and 1000 yr ago established populations were stable in size (except at Brandt's Lake, where an increase in beech pollen is noted $1400 \mathrm{yr}$ ago [Fig. 5]), and no new sites were colonized.

During the last millennium, a pulse of expansion led to colonization of a narrow band of sites along the modern range margin. About $1000 \mathrm{yr}$ ago beech first

FIG. 3. Diagrams showing pollen percentages for major terrestrial types throughout the Holocene for Kitchner (a, site 8) and Spirit (b, site 13) Lakes. Shaded curves are pollen percentages, open curves are percentages multiplied by 10 . Pine pollen is shown separately for diploxylon and haploxylon types and as a single summed curve (the "total Pinus" includes pine grains that were torn or otherwise unidentifiable as haploxylon or diploxylon; Kitchner Lake, in particular, contained many such).

Tree pollen types not shown include Acer spicatum, Juglans cinerea, J. nigra, Platanus occidentalis, Populus spp., Carya spp., and Celtis occidentalis; for these species pollen generally occurred as single grains at scattered levels. Shrub species include Alnus spp., Salix spp., Corylus spp., Shepherdia canadensis, S. argentea, Sambucus pubens, and Cornus spp. Herbs represented in the pollen assemblages include Ambrosia, Artemisia, other Asteraceae, Rumex, Cornus canadensis, Lycopodium spp., Pteridium aquilinum, other ferns, and species of Cyperaceae, Poaceae, and Plumbaginaceae. 


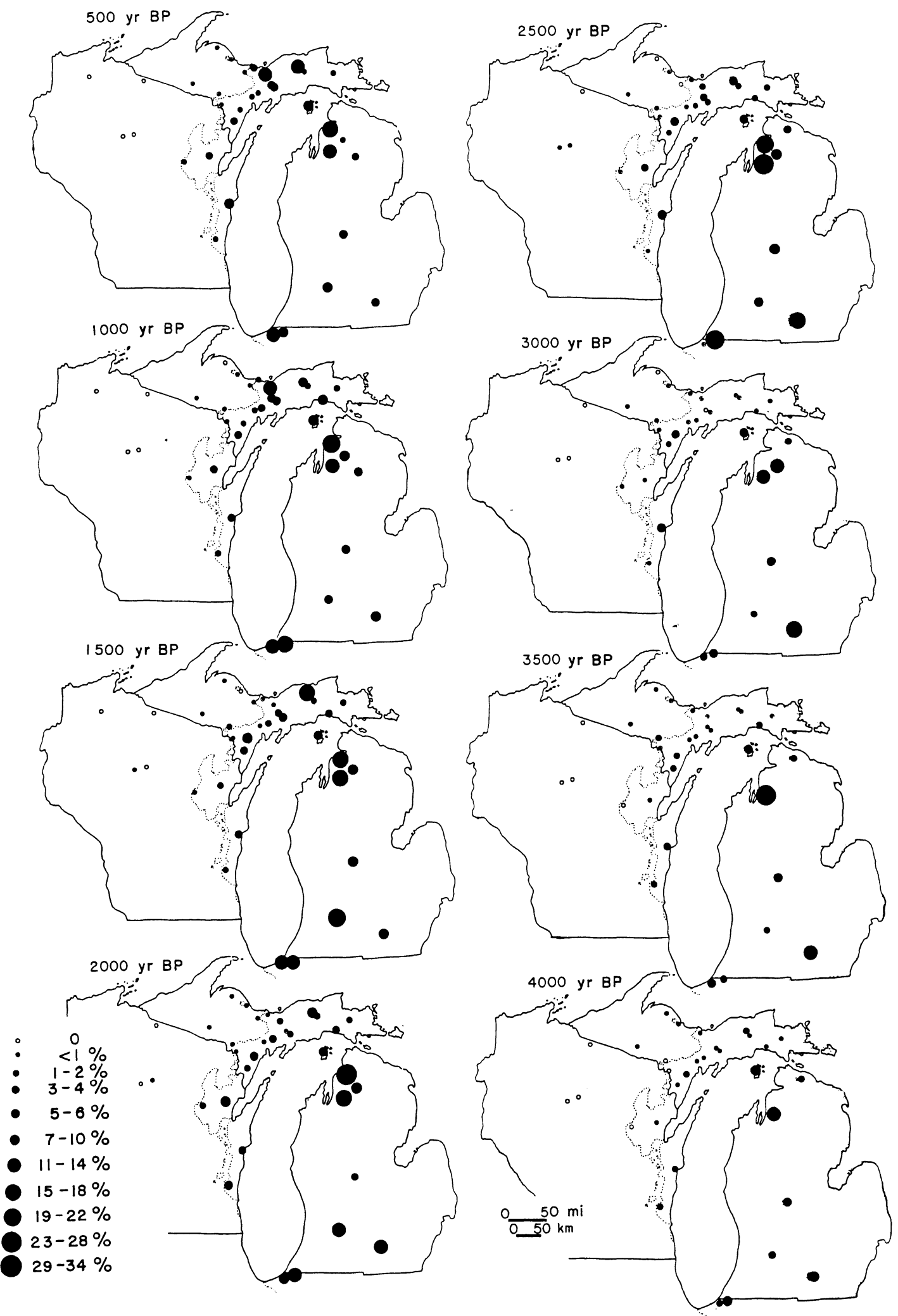

FIG. 4. Maps showing beech pollen percentages at Michigan and Wisconsin sites at 500-yr intervals. All sites shown in Fig. 2 are incorporated. Percentages shown are those for the counted level closest to the indicated age. Some cores are incomplete; these sites are not shown on maps for ages greater than the oldest sampled sediments. Early Holocene shorelines for Lakes Michigan and Huron are shown by dashed lines. 


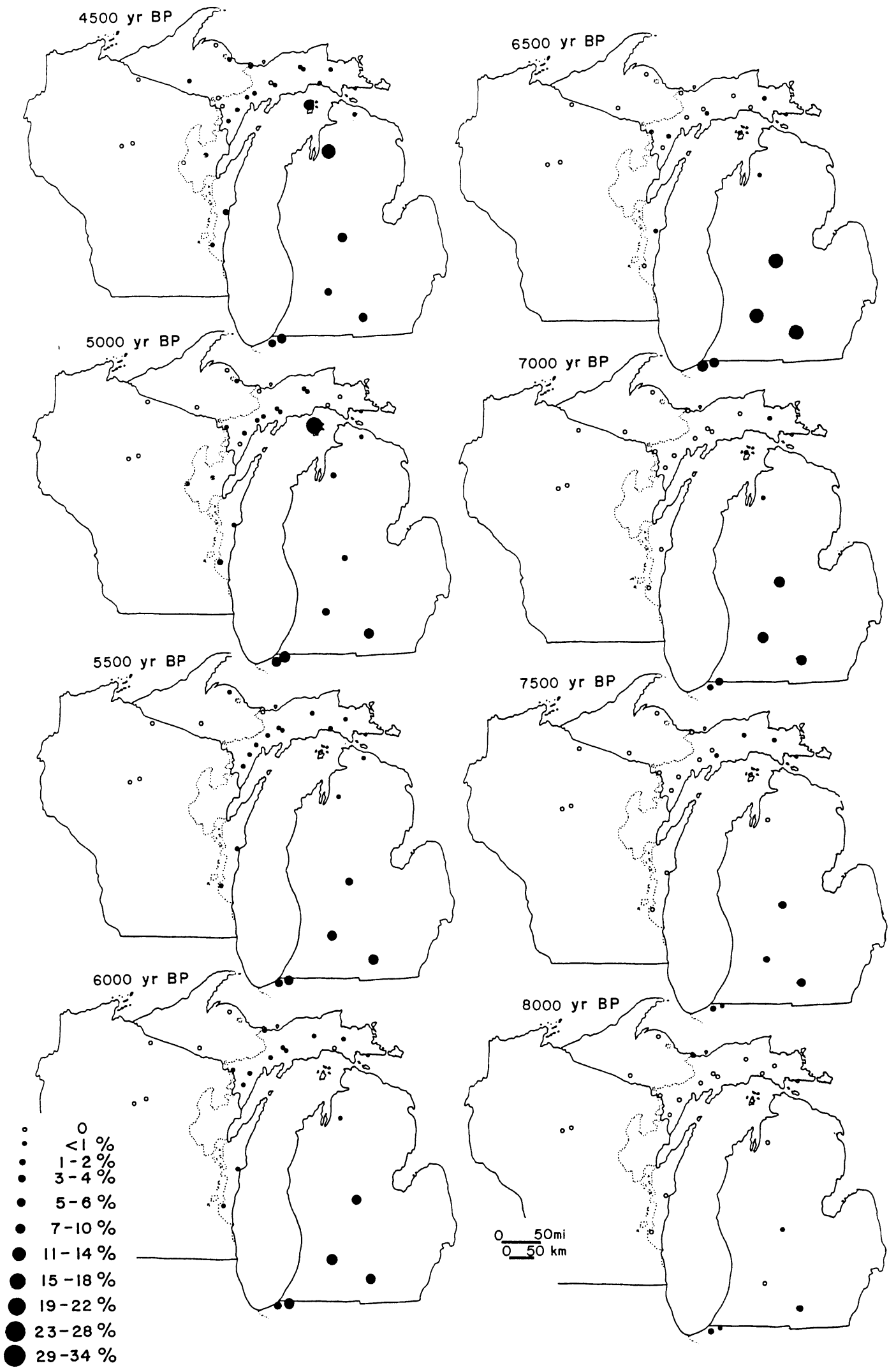

FIG. 4. Continued. 


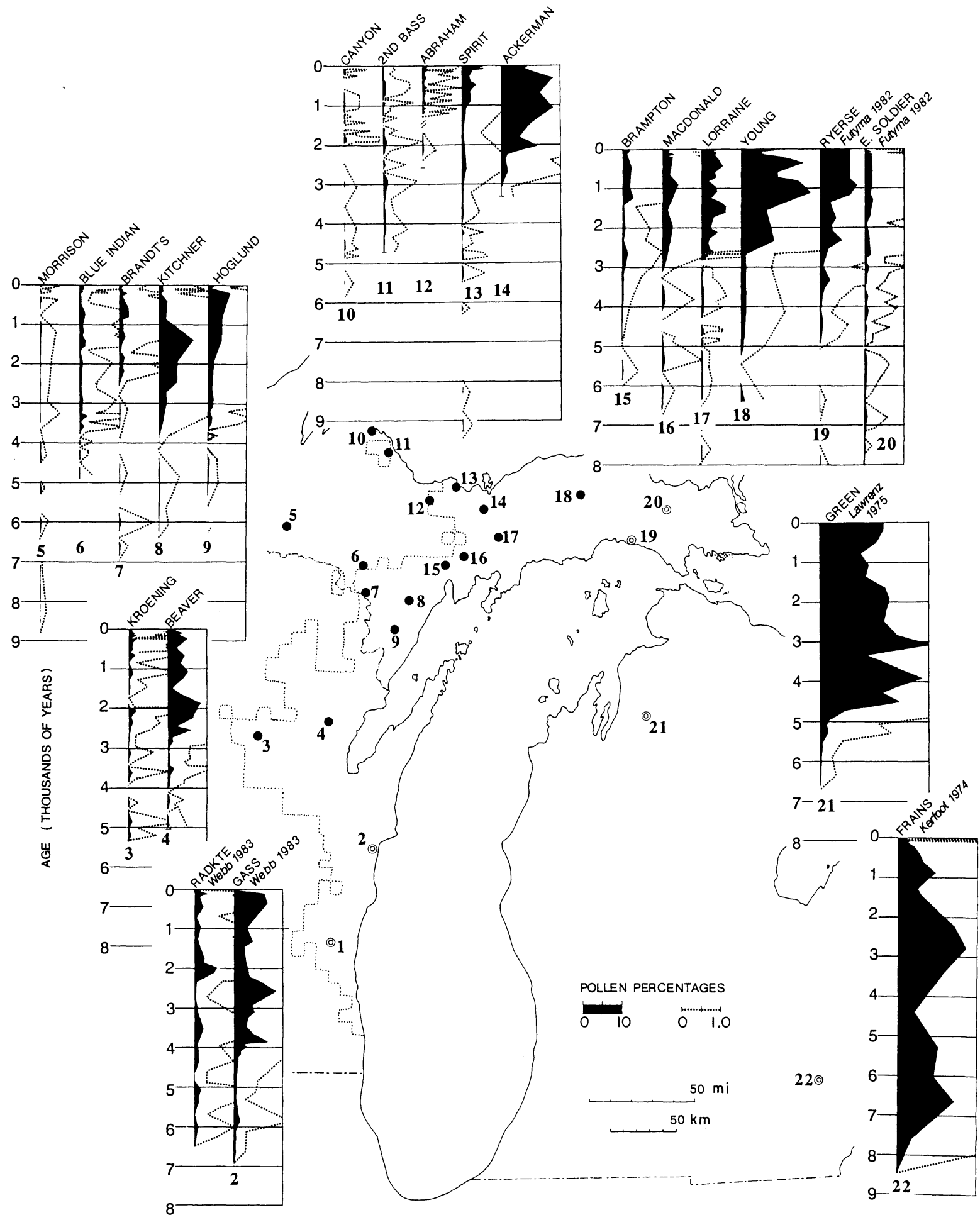

Fig. 5. Curves showing beech pollen percentages plotted against age in thousands of radiocarbon years for selected sites. Beech range limit, generalized to township, is shown by the dotted line. (0) sites from the literature. Curves are shown for all unpublished sites (๑) used. Site numbers are given at the bottom of each curve. Vertical scales are in thousands of years before present. Dotted curves (unshaded) are pollen percentages multiplied by 10 . 
appeared near Spirit (site 13) and Abraham Lakes (site 12 ) in the northwest, and the northwestern outlier near Second Bass Lake (site 11) was apparently established (Fig. 5). Beech populations in the vicinity of Spirit Lake rapidly increased to high levels (Fig. 1). Beech also became established at this time around Blue Indian Lake (site 6), at the modern range limit directly north of Brandt's Lake. (Pollen representation at sites 11 and 12 remained at marginal levels, but the absence of consistent beech pollen representation prior to 1000 $\mathrm{yr}$ ago and the existence of modern populations of beech support the interpretation of establishment within the last millennium.) Populations in southern upper Michigan (sites 7-9) came into apparent contact with populations in the eastern Upper Peninsula (sites 12 $14,16-20)$ during this period with establishment of beech in the vicinity of Brampton Lake (site 15) (Fig. 5). Contemporaneous establishment or population increase of beech at Kroening Lake (site 3) at the westernmost limit of beech in Shawano County, Wisconsin (Fig. 5) shows beech populations to have been affected over a wide geographical area. Diagrams from eastern sites where beech was already established-Lorraine, Ryerse, Young, and Brandt's Lakes-also show population growth during the last $1000 \mathrm{yr}$ (Figs. 4 and 5).

Interpretation of diagrams from some sites is made difficult by the consistent occurrence of beech pollen in low frequencies pre-dating a major increase to levels definitely indicating local presence (Fig. 5). For example, Spirit, Abraham, and Kroening Lakes all show increases around $1000 \mathrm{yr}$ ago, but continuous (or nearly continuous) low percentages (usually $<0.5 \%$ ) in older sediments (Blue Indian Lake shows a similar pattern, but somewhat earlier). These sites are all within $40 \mathrm{~km}$ of sites that showed large local populations during the period of ambiguity. The low percentages may be interpreted as pollen transported from large populations at distances of a few tens of kilometres. The oldest levels with beech pollen at the "younger" sites are generally the same age as sediments first containing high beech pollen percentages at the "older" sites (Fig. 5). Alternatively, these low percentages may indicate sparse, even intermittent, local populations (Bennett 1985); we cannot distinguish between these possibilities.

\section{Discussion}

Seed dispersal, environment and control of range expansion.-How did seed dispersal and environment determine the range of beech? The expansion of beech's range in the last $7000 \mathrm{yr}$ has been irregular, including both periods of rapid expansion and intervals of relative stability. Davis (1981) estimates rates of $200 \mathrm{~m} /$ $\mathrm{yr}$ for beech range extension at a continental scale, and our regional history shows rates occasionally matching or exceeding this. Given its manifest capacity for rapid expansion, lack of evident expansion of beech at the resolution of our grid for a millennium or more must be evidence either of barriers to dispersal or of environmental limits. Resumed expansion implies either (1) dispersal across a major barrier, (2) a change in patterns of environmental limiting factors, or (3) genetic changes in tolerance of the species. Our data do not allow us to address the third possibility, but we may assess the relative importance of the first two.

The modern existence of outlying populations of beech $<1000 \mathrm{yr}$ old, and the establishment in the past of several outliers beyond water barriers, indicate a capacity for long-distance seed dispersal with nontrivial frequency. Mechanisms for frequent dispersal of beech seeds over distances of tens of kilometres have been postulated. Blue Jays (Cyanocitta cristata) have been observed to carry beechnuts up to $4 \mathrm{~km}$ and bury them (Johnson and Adkisson 1985). S. Webb (1983, 1986, 1987) discusses means of long-distance transport of beechnuts, including movement by Passenger Pigeons (Ectopistes migratorius), which may have carried nuts over barriers as wide as Lake Michigan. Nonetheless, colonies of beech on the western shore of Lake Michigan (in Wisconsin at sites 1 and 2 and in Michigan at sites 8 and 9) lagged establishment of populations on the eastern shore by $\approx 1000 \mathrm{yr}$. This delay may be attributable to the infrequency of dispersal of seeds across the lake.

Other changes in the rate of expansion are difficult to attribute solely to delays in dispersal. In these cases, the alternative explanation of climatic change favorable to beech must be entertained. For example, no apparent dispersal barriers prevented early expansion of beech populations along most of the western shore of Lake Michigan (between sites 1-2 and sites 8-9), but the expansion did not occur for several thousand years after the first colonization of the western shore. T. Webb (1986) suggested that cold winter temperatures slowed the northward expansion of beech in Quebec during the mid-Holocene. A similar phenomenon could have been effective here, but entirely different factors might be active at the western range margin.

The appearance of beech populations at sites throughout eastern upper Michigan 2800-2600 yr ago was delayed by $\approx 1500 \mathrm{yr}$ after establishment in adjacent lower Michigan and southern upper Michigan. Potential dispersal barriers, the Straits of Mackinac to the southeast and drier sandy soils around site 15 (Brampton Lake) to the southwest, seem inadequate to account for this delay. In fact, this episode may be interpreted as an expansion of undetected, isolated preexisting populations following environmental change (see Models of Range Expansion, below). Near-simultaneous establishment of beech at sites in eastern Wisconsin ( 3 and 4$)$ and at site 7 support the possibility of regional climate change.

Finally, establishment of populations near the modern range limit of beech (sites 6, 11-13,15) was apparently delayed by $1000-1500$ yr following establishment of populations only $30-50 \mathrm{~km}$ to the east. Here 
no dispersal barrier is conceivable. Modern populations show no discontinuities in these areas. The Brampton Lake (site 15) area was bracketed by older populations nearby to the east and the south. These patterns and simultaneous growth of established populations at Lorraine, Ryerse, Young, and Brandt's Lakes allow only one interpretation of this most recent expansion; it must have been due to climatic change favorable to beech. Lack of corresponding increase at two nearby sites, Wolverine and East Soldier Lakes, proves the rule; both are on coarse, sandy soils where edaphic conditions may have negated effects of ameliorating moisture conditions (Brubaker 1975, Bernabo 1981).

Ecological and silvicultural information suggests that beech in the Midwest is sensitive to several aspects of climate. Modern beech distribution in the Midwest is strongly correlated with continentality of climate. T. Webb (1986) and S. Webb (1987) suggest winter temperatures as a correlate of the beech range limit, while Woods (1981) shows that isoclines of annual temperature range parallel the range limit. Woods (1981) found beech abundance in mature forests in Michigan and Wisconsin positively correlated with evenness of precipitation throughout the year and negatively correlated with annual temperature range. Fritts (1962) and Diller (1935) found increased diameter growth of Midwestern beech in cool, moist summers.

These patterns suggest, then, that we should look for changes toward moister or more equable (less summerwinter differential) climates corresponding with expanding range of beech. The seasonality of solar radiation has decreased due to orbital changes over the period studied here (Kutzbach 1981, Kutzbach and Guetter 1986). Miller and Futyma (1987) document rising groundwater levels in northern lower Michigan beginning $\approx 8000 \mathrm{yr}$ ago. There is evidence along the northern prairie border for a progressive increase in precipitation after $\approx 6000$ yr ago (Webb et al. 1983, Bartlein et al. 1984). These changes may be related to the initial expansion of beech through lower Michigan. Sudden climatic changes corresponding to the beech expansion of 2800-2600 yr ago have not been reported for North America, although they are well documented in Europe (e.g., Van Geel 1978); the expansion of beech, along with increases in pollen of spruce and other mesic species (see Fig. 3) in our study area, may be evidence for a corresponding change in North America. Futyma (1982) documents a rise in water table in eastern upper Michigan after $3000 \mathrm{yr}$ ago (also see Winkler et al. 1986). Range expansions and population increases during the last $1000 \mathrm{yr}$ may document the onset of moister climate with cooler summers during the Little Ice Age (Wahl 1968, Swain 1978, Bernabo 1981, Grimm 1983, 1984).

There is strong circumstantial evidence that substrate is also involved in limitation of beech's distribution. The current range limit in much of the Upper
Peninsula of Michigan is closely associated with a transition from Paleozoic bedrock and glacial drift of relatively high calcium content in the east, to Precambrian granitic bedrock to the west. The argument for causality in this association is strengthened by the observation that outlying beech populations on the granitic shield (in the vicinity of site 11) grow on tills of peculiarly high calcium content (J. Johnson, S. Shetron, Michigan Technical University, personal communication).

Beech may also be limited to finer soils in our study area. In northeastern Wisconsin, the range limit is at the border of an area of coarse, sandy outwash. Lacunae or areas of sparse population within the range of beech often correspond with similar features. Wolverine and Young Lakes (sites 18 and 32) are only $10 \mathrm{~km}$ apart (Fig. 2), but at Wolverine, surrounded by coarse sandy soils, beech pollen percentages never exceed 2-3\% (Table 1). At Young Lake, on finer sandy soils where beech grows today, pollen abundance is greater initially and increases to $15 \%$ (Table 1).

An interaction between climate and substrate is probable. Cooling and increased rainfall should make coarse, droughty soils more tolerable if moisture is limiting. The most recent expansion appears to have involved colonization or increase in sandy areas (Brampton and Ackerman Lakes; sites 14 and 15) where the effects of droughty soils may have been ameliorated by climatic changes of the Little Ice Age. In general, maximum abundance of beech occurs on clay-rich, calcareous soils near shores of Lake Michigan and Lake Superior (Fig. 1), locations where precipitation is high and where extremes of temperature are mitigated.

As a general finding, the range expansion of beech over the last several millennia appears to be more generally limited by frequency of successful seedling establishment, a function of environment, than by seed dispersal. Dispersal limitations may have occasioned delays of about a millennium in colonization of sites in southern Wisconsin (Radtke and Gass Lakes; sites 1 and 2) and southern upper Michigan (Hoglund and Kitchner Lakes; sites 8 and 9) following establishment of populations immediately across Lake Michigan. Even in these cases, however, environmental change may have played a role; the probability of successful establishment following long-distance dispersal will be greatly increased by increasing the number of suitable microsites available.

Models of range expansion. - We have described alternative "wave-front" and outlier models for range expansion. The outlier model postulates expansion by continual establishment of outlying populations followed by their expansion and merger. Our data do not lend explicit support to this model. At least two modern outliers exist, but these are young and we cannot predict whether they will expand. We have no clear evidence of previous outliers, later merged with the main range of beech, except for those established in 
initial crossings of a large water barrier (Lake Michigan). Any rejection of the outlier model, however, can only be for specific scales. As discussed earlier, it is possible, even in the densest portion of our array of sites, that outlying populations may have existed undetected, for example, in the eastern Upper Peninsula before the expansion $2800-2600$ yr ago. A finer grid might have produced support for the outlier model.

Interpretation of this expansion as a "wave-front" phenomenon requires rates of range extension of 200 $300 \mathrm{~m} / \mathrm{yr}$. Although Davis (1981) calculates average Holocene rates for beech of $200 \mathrm{~m} / \mathrm{yr}$, Davis and Botkin (1985) suggest such rates may be unlikely, even for late-successional species like beech, unless accompanied by disruption of existing communities to facilitate establishment and growth to reproductive age. However, the pollen record does not suggest major regional disturbance during the expansion in Michigan; there is no increase in pollen representation of early successional species (see, for example, Fig. 3).

The most likely picture of this region $4000-2800 \mathrm{yr}$ ago may, then, include scattered, small populations of beech on particularly favorable sites. Failure of such populations to expand earlier is strong evidence of environmental limitations. This hypothesis is difficult to test because of the limited dispersal of beech pollen; very carefully (or luckily) selected sites would be required to establish the presence of small, local populations. Acceptance of this hypothesis requires interpreting the rapid expansion of 2800-2600 yr ago as a response to environmental change that made previously unsuitable, perhaps droughty, soils suitable for growth of beech. Other data cited here are consistent with this interpretation.

Community response to beech invasion and climatic change. - Past theories of the nature of communities have suggested that communities should "resist" intrusion by new species (Elton 1958), which might result in restructuring of the community. Our observations better fit Gleason's (1926) individualistic hypothesis, which would predict neither "resistance" to invasion as an emergent property of communities nor overall upheaval following invasion. Beech seedlings, which are shade tolerant, should become established in closed forests if climate and substrate are suitable. Henry and Swan (1974) showed that beech establishment during a 200-yr interval in a New Hampshire forest occurred independently of disturbance events. Woods (1981) describes all-age age structures of beech in old-growth forests of the upper Midwest. Woods $(1979,1984)$ and T. L. Poulson (University of Illinois, Chicago, personal communication) documented survival of beech seedlings and saplings for long periods under suppression by sugar maple and other codominant species. Data presented here show that beech expanded rapidly in a forested landscape in which white pine, sugar maple, birch, and hemlock were the dominant trees. The pollen record from lakes contains no clear evidence of regional disruption (as distinct from on-going local, gap-phase phenomena) of forests just prior to or during periods of range expansion or population growth (e.g., Fig. 3); pollen assemblages in most instances change little.

Stability of modern range limit. - Major changes in range limit in the recent past suggest the question, "Is the present range limit stable, or expanding?" Pollen records at most sites show decreases in beech pollen percentages since settlement (also see T. Webb 1973), but these are likely due to agricultural use of richer soils, where beech grows best, or to slow regeneration of beech following logging and burning. Available data on beech age structure near the range limit are not helpful either, because these data span a time too brief to show clear trends. Some anecdotal evidence is consistent with a continuing expansion. Beech seedlings and saplings have been observed several kilometres from the nearest mature trees along the northwestern range limit. Near Abraham Lake, surveys in the United States Forest Service's Upper Peninsula Experimental Forest have shown saplings and seedlings to be present some hundreds of metres west of the apparent limit of canopy individuals (F. Metzger, United States Forest Service, personal communication). These seedlings and saplings, however, may not persist to maturity.

\section{SUMMARY AND CONCLUSIONS}

Past locations of the range limit of beech in the Upper Great Lakes region, as interpreted from the pollen record, show range expansion during the last $7500 \mathrm{yr}$ to have been irregular, with at least two distinct periods of expansion with intervening periods of relative stability. Expansion of beech throughout lower Michigan and into southeast Wisconsin (S. Webb 1983, 1987) took place 7500-5000 yr ago. Due either to the barrier to dispersal created by Lake Michigan, or to unfavorable environment, beech did not enter Michigan's Upper Peninsula immediately. Early colonies in upper Michigan were established $\approx 4000$ yr ago but expanded slowly if at all. Rapid expansion of populations and possibly extension of range resumed between 3000 and $2500 \mathrm{yr}$ ago in the eastern Upper Peninsula of Michigan and eastern Wisconsin. A second period of relative stability lasted $\approx 1500 \mathrm{yr}$, ending within the last millennium, when beech pollen increased at five sites near the boundaries of its current range from its northern limit in Michigan to central Wisconsin.

This history shows that (1) range expansion and population growth of beech did occur at a variable rate in this region, (2) populations of beech on the western and northern shores of Lake Michigan stem from several independent colonizations, and (3) variations in rates of range expansion were primarily due to environmental limitation, although barriers to dispersal may have slowed expansion across Lake Michigan. Beech has been in approximate equilibrium with climate during most of the last 5000, and possibly 8000 , yr. Al- 
though all detected range changes have been expansions, it seems unlikely that climatic change over five millennia has been uniformly beneficial for beech. Once established, beech may be tolerant of a wider range of conditions than it is in the establishment phase, or tolerances, once populations are established, can evolve rapidly enough to track the environmental changes that have occurred. Davis and Botkin (1985) show that, in simulation models of established forests, compositional change lagged environmental change by decades or centuries due to the longevity and tolerance of mature trees. This process could produce disequilibrium (cf. T. Webb 1986) of climate and vegetation if climate changes with a periodicity not much longer than the lag time. (Vegetation composition might continuously lag longer term changes in climate, but still not be in "disequilibrium.") Disequilibria, although brief, may be exemplified here.

We show that fossil pollen data from a grid of closely spaced sites can allow more conclusive interpretation of low pollen frequencies (see Bennett 1985) and fluctuations than can diagrams from isolated sites. The grid permits better understanding of routes and speeds of expansion and permits identification of at least some isolated outlying populations. Pollen deposition from sparse, local populations and pollen dispersed from larger, more distant populations cannot be distinguished in a single diagram; a landscape grid allows at least tentative distinction.

\section{ACKNOWLEDGMENTS}

The data we used incorporate the work of many people. We are particularly grateful to Richard Futyma of the University of Michigan for permission to use several unpublished pollen diagrams from Michigan. Pollen counts for some diagrams were made by Mike Dahlberg, Rudy Nickmann, Jim Ogg, Jim Mack, and Jane Beiswenger. Land Office survey data for Wisconsin were compiled by Mark Schwartz. We had field assistance from Taber Allison, Owen Davis, Judy Gennett, Bob Sterner, Mike Dahlberg, Caz Lewis, Rudy Nickmann, Peter Salamun, and Gurdip Singh. We are grateful to landowners for access to sites in Michigan and Wisconsin and to various people for help in locating peripheral populations of beech. Extensive reviews by T. Webb III, D. C. Gaudreau, and an anonymous reviewer have been particularly helpful.

\section{LITERATURE Cited}

Allison, T., R. E. Moeller, and M. B. Davis. 1986. Pollen in laminated sediments provides evidence for a mid-Holocene forest pathogen outbreak. Ecology 67:1101-1105.

Bailey, R. E. 1972. Vegetation history of northwest Indiana. Dissertation. Indiana University, Bloomington, Indiana, USA.

1977. Pollen stratigraphy of Wintergreen Lake. Page 24 in R. O. Kapp, editor. Handbook for paleoecology field trip in central lower Michigan. Ecological Society of America, Lansing, Michigan.

Bartlein, P. J., T. Webb III, and E. Fleri. 1984. Holocene climatic change in the northern Midwest: pollen-derived estimates. Quaternary Research 22:361-374.

Bennett, K. D. 1985. The spread of Fagus grandifolia across eastern North America during the last 18000 years. Journal of Biogeography 12:147-164.

Benninghoff, W. S. 1962. Calculation of pollen and spore density in sediments by addition of exotic pollen in known quantities. Pollen et Spores 4:332-333.

Bernabo, J. C. 1981. Quantitative estimates of temperature changes over the last 2700 years in Michigan based on pollen diagrams. Quaternary Research 15:143-159.

Bernabo, J. C., and T. Webb III. 1977. Changing patterns in the Holocene pollen record of northeastern North America: a mapped summary. Quaternary Research 8:64-96.

Birks, H. J. B. 1981. The use of pollen analysis in the reconstruction of past climates: a review. Pages 111-138 in T. M. L. Wigley, M. J. Ingram, and G. Farmer, editors. Climate and history. Cambridge University Press, Cambridge, England.

Bourdo, E. A., Jr. 1956. A review of the general land office survey and of its use in quantitative studies of former forests. Ecology 37:754-768.

Bradshaw, R. W., and T. Webb III. 1985. Relationships between contemporary pollen and vegetation data from Wisconsin and Michigan, U.S.A. Ecology 66:721-737.

Braun, E. L. 1950. Deciduous forests of eastern North America. Blakiston, Philadelphia, Pennsylvania, USA.

Brown, J. H. 1984. On the relationship between abundance and distribution of species. American Naturalist 124:255279.

Brubaker, L. B. 1975. Post-glacial forest patterns associated with till and outwash in Northcentral Upper Michigan. Quaternary Research 5:499-527.

Q 1986. Population responses of forest trees to climatic change. Vegetatio 67:119-130.

Conolly, A. P., and E. Daht: 1970. Maximum summer temperature in relation to the modern and Quaternary distributions of certain arctic-montane species in the British Isles. Pages 159-224 in D. Walker and R. G. West, editors. Studies in the vegetational history of the British Isles. Cambridge University Press, Cambridge, England.

Curtis, J. T. 1959. The vegetation of Wisconsin. University of Wisconsin Press, Madison, Wisconsin, USA.

Daubenmire, R. 1968. Plant communities. Harper and Row, New York, New York, USA.

Davis, M. B. 1976. Pleistocene biogeography of temperate deciduous forests. Geoscience and Man 13:13-26.

- 1978. Climatic interpretation of pollen in Quaternary sediments. Pages 35-51 in D. Walker and J. C. Guppy, editors. Biology and Quaternary environments. Australian Academy of Science, Canberra, Australia.

1981. Quaternary history and the stability of deciduous forests. Pages 132-153 in D. C. West, H. H. Shugart, and D. B. Botkin, editors. Forest succession: concepts and applications. Springer-Verlag, New York, New York, USA.

Davis, M. B., and D. B. Botkin. 1985. Sensitivity of cooltemperate forests and their fossil pollen record to rapid temperature change. Quaternary Research 23:327-340.

Davis, M. B., L. B. Brubaker, and J. M. Beiswenger. 1971. Pollen grains in lake sediments: pollen percentages in surface sediments from southern Michigan. Quaternary Research 1:450-467.

Davis, M. B., K. D. Woods, S. L. Webb, and R. P. Futyma. 1986. Dispersal versus climate: expansion of Fagus and Tsuga into the upper Great Lakes Region. Vegetatio 67: 93-103.

Davis, R. B., and G. L. Jacobson, Jr. 1985. Late glacial and early Holocene landscapes in northern New England and adjacent areas of Canada. Quaternary Research 23:341368.

Diller, O. D. 1935. The relation of temperature and precipitation to the growth of beech in northern Indiana. Ecology 16:72-81.

Elton, C. S. 1958. The ecology of invasions by animals and plants. Methuen, London, England.

Faegri, K., and J. Iversen. 1975. Textbook of pollen analysis. Blackwell, London, England. 
Fowells, H. A. 1965. Silvics of forest trees of the United States. United States Department of Agriculture Handbook 271. United States Government Printing Office, Washington, D.C., USA.

Fritts, H. C. 1962. The relation of growth ring widths in American beech and white oak to variations in climate. Tree-Ring Bulletin 25:2-10.

Futyma, R. P. 1982. Postglacial vegetation of eastern Upper Michigan. Dissertation. University of Michigan, Ann Arbor, Michigan, USA.

Gilliam, J. A., R. O. Kapp, and R. D. Bogue. 1967. A postWisconsin pollen sequence from Vestaburg Bog, Montcalm County, Michigan. Michigan Academy of Sciences, Arts, and Letters 52:3-17.

Gleason, H. A. 1926. The individualistic concept of the plant association. American Midland Naturalist 21:92-108.

Grimm, E. C. 1983. Chronology and dynamics of vegetation change in the prairie-woodland region of southern Minnesota, U.S.A. New Phytologist 93:311-350.

- 1984. Fire and other factors controlling the Big Woods vegetation of Minnesota in the mid-nineteenth century. Ecological Monographs 54:291-311.

Heide, K. M. 1981. Late-Quaternary vegetational history of north-central Wisconsin, USA: estimating forest composition from pollen data. Dissertation. Brown University, Providence, Rhode Island, USA.

Henry, J. D., and J. M. A. Swan. 1974. Reconstructing forest history from live and dead plant material-an approach to the study of forest succession in southwest New Hampshire. Ecology 55:772-783.

Iversen, J. 1944. Viscum, Hedera and Ilex as climatic indicators. Geologiska Foreningens i Stockholm Forhandlingar 66:463-483.

Jacobson, G. L., Jr. 1979. The palaeoecology of white pine (Pinus strobus) in Minnesota. Journal of Ecology 67:697726.

Jensen, J. 1928. The native beeches in the Chicago region. Transactions of the Illinois State Academy of Science 21: 69-71.

Johnson, W. C., and C. S. Adkisson. 1985. Dispersal of beechnuts by Blue Jays in fragmented landscapes. American Midland Naturalist 113:319-324.

Kapp, R. O. 1977. Late Pleistocene and post-glacial plant communities of the Great Lakes Region. Pages 1-27 in R. C. Romans, editor. Geobotany. Plenum, New York, New York. USA.

Kapp, R. O., S. Bushouse, and B. Foster. 1969. A contribution to the geology and forest history of Beaver Island, Michigan. Pages 225-236 in Proceedings of the 12th Conference on Great Lakes Research. International Association for Great Lakes Research, University of Michigan, Ann Arbor, Michigan, USA.

Kerfoot, W. C. 1974. Net accumulation rates and the history of cladoceran communities. Ecology 55:51-61.

Kuchler, A. W. 1966. Potential natural vegetation of the conterminous United States. American Geographical Society, New York, New York, USA.

Kutzbach, Z. 1981. Monsoon climate of the early Holocene: climate experiment with the earth's orbital parameters for 9000 years ago. Science 214:59-61.

Kutzbach, Z., and P. J. Guetter. 1986. The influence of changing orbital parameters and surface boundary conditions on the climate simulations for the past 18000 years. Journal of Atmospheric Science 43:1726-1759.

Lawrenz, R. W. 1975. The developmental paleoecology of Green Lake, Antrim County, Michigan. Thesis. Central Michigan University, Mount Pleasant, Michigan, USA.

Little, E. L., Jr. 1970. Atlas of United States trees. Volume 1. Conifers and important hardwoods. United States Forest Service Miscellaneous Publication Number 1146.

Manny, B. A., R. G. Wetzel, and R. E. Bailey. 1978. Paleolimnological sedimentation of organic carbon, nitrogen, phosphorus, fossil pigments, pollen, and diatoms in a hypereutrophic, hardwater lake: a case history of eutrophication. Polskie Archiwum Hydrobiologii 25:243-267.

Miller, N. G., and R. P. Futyma. 1987. Paleohydrological implications of Holocene peatland development in northern Michigan. Quaternary Research 27:297-311.

Moran, R. C. 1978. Vascular flora of the ravines along Lake Michigan in Lake County, Illinois. Michigan Botanist 17: 123-140.

Pennington, W. (Mrs. P. G. Tutin). 1986. Lags in adjustment of vegetation to climate caused by the pace of soil development. Vegetatio 67:105-118.

Pielou, E. C. 1979. Biogeography. Wiley-Interscience, New York, New York, USA.

Pigott, C. D., and J. P. Huntley. 1978. Factors controlling the distribution of Tilia cordata at the northern limits of its geographical range. New Phytologist 81:429-441.

Prentice, I. C. 1986. Long-term processes, response times and equilibrium in vegetation. Vegetatio 67:131-142.

Schwartz, M. 1985. Improving regression techniques to establish the vegetation-pollen relationship. Thesis. University of Minnesota, Minneapolis, Minnesota, USA.

Stowe, L. G., and J. A. Teeri. 1978. The geographic distribution of C-4 species of the Dicotyledonae in relation to climate. American Naturalist 112:609-623.

Swain, A. M. 1978. Environmental changes during the last 2000 years in north-central Wisconsin: analysis of pollen, charcoal and seeds from varied lake sediments. Quaternary Research 10:55-68.

Teeri, J. A., L. G. Stowe, and D. A. Murawski. 1978. The climatology of two succulent families, Cactaceae and Crassulaceae. Canadian Journal of Botany 56:1750-1758.

Van Geel, B. 1978. A palaeoecological study of Holocene peat bog sections in Germany and the Netherlands. Review of Paleobotany and Palynology 25:1-120.

Wahl, E. W. 1968. A comparison of the climate of the eastern United States during the 1830's with the current normals. Monthly Weather Review 96:73-82.

Webb, S. L. 1983. The Holocene extension of the range of American beech (Fagus grandifolia) into Wisconsin: paleoecological evidence for long-distance seed dispersal. Thesis. University of Minnesota, Minneapolis, Minnesota, USA.

- 1986. Potential role of Passenger Pigeons and other vertebrates in the rapid Holocene migrations of nut trees. Quaternary Research 26:367-375.

- 1987. Beech range extension and vegetation history: pollen stratigraphy of two Wisconsin lakes. Ecology 68 : 1993-2005.

Webb, T., III. 1973. A comparison of modern and presettlement pollen from southern Michigan. Review of Palaeobotany and Palynology 16:367-375.

- 1974. A vegetation history from northern Wisconsin: evidence from modern and fossil pollen. American Midland Naturalist 92:12-34.

. 1982. Temporal resolution in Holocene pollen data. Pages 569-572 in Proceedings of the Third North American Paleontological Convention. Volume 2. Business and Economic Service, Toronto, Ontario, Canada.

1986. Is vegetation in equilibrium with climate? How to interpret late-Quaternary pollen data. Vegetatio 67: 75-91.

1987. The appearance and disappearance of major vegetational assemblages: long-term vegetational dynamics in eastern North America. Vegetatio 69:177-187.

Webb, T., III, E. J. Cushing, and H. E. Wright, Jr. 1983. Holocene changes in the vegetation of the Midwest. Pages 142-165 in H. E. Wright, Jr., editor. Late-Quaternary environments of the United States. University of Minnesota Press, Minneapolis, Minnesota, USA.

Winkler, M. G., A. M. Swain, and J. E. Kutzbach. 1986. Middle-Holocene dry period in the northern Midwestern 
United States: lake levels and pollen stratigraphy. Quaternary Research 25:235-255.

Woods, K. D. 1979. Reciprocal replacement and the maintenance of codominance in a beech-maple forest. Oikos 33: 31-39.

1981. Interstand and intrastand pattern in hemlocknorthern hardwood forests. Dissertation. Cornell University, Ithaca, New York, USA.

. 1984. Patterns of tree replacement: canopy effects on understory pattern in hemlock-northern hardwood forests. Vegetatio 56:87-107.

Wright, H. E., Jr. 1967. A square-rod piston sampler for lake sediments. Journal of Sedimentary Petrology 37:975976.

. 1984. Sensitivity and response time of natural systems to climatic change in the late Quaternary. Quaternary Science Review 39:91-131. 